\title{
Roving Survey for Root-Knot Nematode in Major Sweet Potato Growing Districts of Karnataka, India
}

\author{
H. Amaresh ${ }^{1 *}$, V. Kantharaju ${ }^{1}$, S. Amruta Bhat ${ }^{1}$, \\ K. Ramachandra Naik ${ }^{1}$ and Y.S. Mahesh ${ }^{2}$ \\ ${ }^{1}$ K. R. C. College of Horticulture, Arabhavi- 591218, Karnataka, India \\ ${ }^{2}$ College of Horticulture, Bagalkot- 587104, Karnataka, India \\ *Corresponding author
}

Keywords

Social, economic, Drying, Galling, Rotting, Explorers, traders

Article Info

Accepted:

12 September 2019

Available Online:

10 October 2019

\section{A B S T R A C T}

Sweet potato, Ipomoea batatas (L.) Lam., is a dicotyledous plant that belongs to the family Convolvulaceae. A number of plant parasitic nematodes have been reported to be associated with sweet potato in India and among the species identified, Meloidogyne incognita is one of the economically important nematode which makes the way for the secondary infection by different pathogens like Pythium, Fusarium and Ralstonia in the soil. A roving survey was conducted for incidence of root-knot nematode in sweet potato during kharif season in 2018-2019 at Bidar, Bagalkot, Vijayapura, Belagavi, Dharwad and Chikkamagaluru districts of Karnataka. Survey conducted in eight taluks comprising of 38 fields, the major symptoms recorded during survey are having root galls, yellowing, marginal and tip drying of leaves and galling and rotting of roots. The results revealed that highest root-gall index was recorded in Belagavi followed by Dharwad, Bagalkot, Bidar, Mudigere districts. The lowest incidence was observed in Vijayapura.

\section{Introduction}

Sweet potato, Ipomoea batatas (L.) Lam., is a dicotyledous plant that belongs to the family Convolvulaceae. It is originated from Central America and the North Western part of South America from where it was introduced to Europe by Columbus and to Asia, Africa and
North America by Spanish and Portuguese explorers and traders. It is an herbaceous perennial crop with edible tuberous root that is usually long and tapered, with a smooth skin whose colour ranges between red, purple, brown and white. It can be cultivated throughout the tropical and warm temperature region wherever there is sufficient water to 
support their growth. It is a vegetable crop with great social, economic and nourishing importance, especially for the poorest regions of the planet, where it is one of the most important food sources (Oliveira et al., 2005).

Sweet potato is a perennial vine, usually cultivated as an annual crop. Its storage roots are rich in energy and are an important source of carbohydrates, vitamin A and C, fiber, iron, copper, calcium and folic acid, especially the orange-fleshed sweet potatoes (Collins et al., 1999).

Sweet potato is mainly grown in China, Nigeria, Tanzania, Ethiopia and Indonesia. The crop is grown in all states of India, except Jammu and Kashmir, Himachal Pradesh and Sikkim. It can be grown in different environments and it became an excellent supplement to staple foods. In India, it is grown in an area of 1.39 lakh hectares with a production of 16.38 lakh tonnes having productivity of 12.2 MT per hectare.

In India, it is mainly grown in Odisha, Kerala, West Bengal, Uttar Pradesh, Chattisgarh, Assam and Maharastra. In Karnataka, it is cultivated in an area of 2.54 thousand hectares with a production of 36 thousand tonnes. The major sweet potato producing districts of the state are Belagavi, Mandya, Dakshina Kannada and Chikmagalur (Anon, 2017).

A number of plant parasitic nematodes have been reported to be associated with sweet potato in India and among the species identified, Rotylenchus reniformis, Helicotylenchus dihystera and Meloidogyne incognita are the one which are economically important (Ramakrishnan and Mohandas, 1996).

A survey is necessary to assess the community structure of plant parasitic nematodes associated with sweet potato. Many biotic and abiotic factors such as soil temperature, soil moisture, soil type, cultural practices, weed hosts and intercropping are known to influence nematode distribution. The survey on root-knot nematode will provide information on incidence, severity and distribution.

\section{Materials and Methods}

A roving (random) survey for plant parasitic nematodes associated with sweet potato was taken up during Kharif /Rabi season in 201819 at Bidar, Bagalkot, Vijayapura, Belagavi, Dharwad and Chikkamagaluru districts of Karnataka (Fig. 1). The sampling was done in plants showing nematode symptoms viz., yellowing, poor growth or stunted growth with reduced leaf size, chlorosis of foliage, wilting and root galls.

\section{Collection of soil and root samples}

Soil and root system samples from 3 to 5 spots were collected randomly with the aid of shovel from the root zone of sweet potato crop. Later, a composite sample of 200cc soil and root system were put in a polythene bag with proper labeling. Information pertaining to the crop, locality, soil condition etc., was also collected along with the samples.

\section{Estimation of nematode population in soil samples}

Soil sample of $200 \mathrm{cc}$ was washed thoroughly and processed using combined "Cobb's sieving and Baermann's funnel method" (Ayoub, 1977) as given below.

Two hundred cc of soil was taken in $1000 \mathrm{ml}$ beaker and sufficient quantity of water was added to make soil solution.

This was stirred thoroughly and allowed to stand for heavier particles to settle down. 
Then the soil solution was passed through a set of sieves of 100, 250, 325 and 400 mesh sizes, respectively. Residue from 325 and 400 mesh sieves were collected and poured over a tissue paper spread on a wire gauge and placed on Baermann's funnel.

Level of water in the Baermann's funnel was maintained to keep the tissue paper wet and left undisturbed for $48 \mathrm{hr}$. After incubation of $48 \mathrm{hr}$, the volume of suspension was made to $200 \mathrm{ml}$, out of which $10 \mathrm{ml}$ was pipetted out and used for counting of various plant parasitic nematodes present. Nematode population from this was finally estimated for 200 cc soil.

Estimation of nematode population in root samples

Nematode population in $10 \mathrm{~g}$ roots was estimated by Root incubation method (Ayoub, 1977) as explained below:

\section{Procedure}

Roots were gently washed to remove adhering soil particles

Washed roots were cut into small bits of 2.5 $\mathrm{cm}$ and split longitudinally.

Then placed over tissue paper spread on a wire gauge and kept in a Petri plate filled with water.

Level of water was maintained in Petri plate and left undisturbed for 48 hours. Later, the suspension in the Petri plate was collected and observed for nematodes using stereo-binocular microscope.

\section{Counting the number of nematodes}

The number of nematodes in an aqueous suspension was determined by using a counting dish. A five $\mathrm{cm}$ diameter glass Petri plate was used as a counting dish. Squares were made on the outer surface of the bottom of the dish to facilitate counting.

A $10 \mathrm{ml}$ volume of aqueous suspension from the beaker was taken and placed into the petriplates. Nematodes were counted in all squares under a stereobinocular microscope. After counting, the suspension was transferred back to the mother container. Counting of each sample was repeated four times in same manner. The mean number of nematodes per $10 \mathrm{ml}$ was determined by averaging the counts taken.

\section{Results and Discussion}

A roving survey was carried out to know the occurrence of plant parasitic nematodes in major sweet potato growing districts viz., Bidar, Bagalkot, Vijayapura, Belagavi, Dharwad and Chikkamagaluru during Kharif, 2018 and the data obtained are depicted in Table 1. The soil and root samples were collected from different places and brought to the laboratory for analysis. The presence of root-knot nematodes was assessed. In Belagavi district, the number of galls per root system was ranged from 10-32. Maximum number of galls (32) was recorded in Kenaye (1) field followed by Kenaye (2) field (31) and Mudekop (2) field (61). Minimum number of galls recorded in Navage (1) field (10) followed by Mudekop (1) field (18) and Hasanwadi (1) field (19).

The maximum gall index (4) was found in Kenaye $(1 \& 2)$ fields, against least gall index (2) from Navage (1) field and remaining fields recorded gall index of (3).

The nematode population per $200 \mathrm{cc}$ soil was ranged from 61-88. The maximum soil nematode population (88) was recorded in Navage (2) field followed by Hasanwadi (2) 
field (81) and Kenaye (2) field (80) as against minimum population in Mudekop (2) field (61) followed by Mudekop (1) field (69) and in Navage (1) field (70).

On an average, the number of galls per root system was 21.50 , gall index of 3.10 and soil nematode population per $200 \mathrm{cc}$ soil was of 74.25 recorded in Belagavi district.

In Bagalkot district, the number of galls per root system was ranged from 9-47 with the maximum of 47 in Mirji (1) field followed by Mirji (2) field (29) and Kesargoppa (1) field (28). The least number of galls was recorded in Mirji (3) field (9) and Kesargoppa (2) field (10).

The maximum gall index (4) was recorded in Mirji (1) followed by Kesargoppa (1, 3 \& 4) fields (3) and minimum (2) in Kesargoppa (2) and Mirji (3) fields. Soil nematode population was ranged from 17-150. The maximum population (150) was recorded in Mirji (1) field followed by Kesargoppa (1) field (100) and Kesargoppa (2) field (87) whereas the least soil nematode population (17) was recorded in Mirji (3) field followed by Kesargoppa (3) field (38) and Mirji (2) field (46).

On an average, the number of galls per root system was 22.50 , gall index of 2.87 and soil nematode population per $200 \mathrm{cc}$ of soil was 65.25 recorded in Bagalkot district.
The results of the survey in Vijayapura district revealed that, the number of galls per root system was ranged from 0-34 with Bommanahalli (3) field was highest (34) followed by Bommanahalli (1) field (15). The least number of galls per root system was recorded in Bommanahalli (4) field (10) and zero galls were recorded in Bommanahalli (2) fields.

The range of gall index was 0-4 with highest in Bommanahalli (3) field (4) followed by Bommanahalli (1) field (3) as against least in Bommanahalli (2) field (0) and in Bommanahalli (4) field (2). The highest soil nematode population $(200 \mathrm{cc}$ ) was observed in Bommanahalli (3) field (52) followed by Bommanahalli (4) field (42), as against minimum (38) from Bommanahalli (1) field and no population in Bommanahalli (2) field.

In Vijayapura district, on an average, the number of galls per root system was 14.75 , gall index of 2.25 and soil nematode population of 33.00 was recorded.

In Dharwad district, the highest number of galls per root system was recorded in Dharwad (2) field (28) followed by Narendra (3) field (22) and Narendra (1) field (19). The least number of galls per root system was recorded in Dharwad (1) field (15). The highest gall index of 3 was recorded in Dharwad $(1 \& 2)$ and Narendra $(1,2 \& 3)$ fields.

Table.1 Incidence of root-knot nematode was recorded by using the gall index given by (Taylor and Sasser, 1978) which is as follows

\begin{tabular}{|c|c|}
\hline Description & Grade \\
\hline No galls or egg masses & 0 \\
\hline 1 to 2 galls or egg masses & 1 \\
\hline 3 to 10 galls or egg masses & 2 \\
\hline 11 to 30 galls or egg masses & 3 \\
\hline 31 to 100 galls or egg masses & 4 \\
\hline More than 100 galls or egg masses & 5 \\
\hline
\end{tabular}


Table.2 Roving survey of root-knot nematode in major sweet potato growing districts of Karnataka

\begin{tabular}{|c|c|c|c|c|c|c|c|c|c|}
\hline District & Taluk & $\begin{array}{l}\text { Sample } \\
\text { number }\end{array}$ & Village & Variety & Season & Soil type & $\begin{array}{c}\text { No. of } \\
\text { galls/root } \\
\text { system }\end{array}$ & $\begin{array}{c}\text { Gall } \\
\text { Index }\end{array}$ & $\begin{array}{c}\text { Nematode } \\
\text { population in } \\
\text { soil }(200 c c)\end{array}$ \\
\hline \multirow{8}{*}{ Belagavi } & \multirow{4}{*}{ Khanapur } & 01 & Mudekop -1 & BSP-23 & Kharif & Red sandyloam & 18 & 3 & 69 \\
\hline & & 02 & Mudekop -2 & BSP-23 & Kharif & Red sandyloam & 25 & 3 & 61 \\
\hline & & 03 & Hasanwadi -1 & BSP-23 & Kharif & Red sandyloam & 19 & 3 & 72 \\
\hline & & 04 & Hasanwadi-2 & BSP-23 & Kharif & Red sandyloam & 22 & 3 & 81 \\
\hline & \multirow{4}{*}{ Belagavi } & 05 & Navage -1 & BSP-23 & Kharif & Red sandyloam & 10 & 2 & 70 \\
\hline & & 06 & Navage -2 & BSP-23 & Kharif & Red sandyloam & 19 & 3 & 88 \\
\hline & & 07 & Kenaye -1 & BSP-23 & Kharif & Red sandyloam & 32 & 4 & 73 \\
\hline & & 08 & Kenaye -2 & BSP-23 & Kharif & Red sandyloam & 31 & 4 & 80 \\
\hline \multicolumn{7}{|c|}{ Total } & 173 & 25 & 594 \\
\hline \multicolumn{7}{|c|}{ Average } & 21.5 & 3.10 & 74.25 \\
\hline \multirow{8}{*}{ Bagalkot } & \multirow{4}{*}{$\begin{array}{l}\text { Rabakavi } \\
\text { banahatti }\end{array}$} & 09 & Kesargoppa-1 & BSP-23 & Kharif & Black soil & 28 & 3 & 100 \\
\hline & & 10 & Kesargoppa-2 & BSP-23 & Kharif & Black soil & 10 & 2 & 87 \\
\hline & & 11 & Kesargoppa-3 & BSP-23 & Kharif & Black soil & 16 & 3 & 38 \\
\hline & & 12 & Kesargoppa-4 & BSP-23 & Kharif & Black soil & 22 & 3 & 84 \\
\hline & \multirow{4}{*}{ Mudhol } & 13 & Mirji-1 & BSP-23 & Kharif & Black soil & 47 & 4 & 150 \\
\hline & & 14 & Mirji-2 & BSP-23 & Kharif & Black soil & 29 & 3 & 46 \\
\hline & & 15 & Mirji-3 & BSP-23 & Kharif & Black soil & 09 & 2 & 17 \\
\hline & & 16 & Mirji-4 & BSP-23 & Kharif & Black soil & 19 & 3 & 55 \\
\hline \multicolumn{7}{|c|}{ Total } & 180 & 23 & 522 \\
\hline \multicolumn{7}{|c|}{ Average } & 22.50 & 2.87 & 65.25 \\
\hline
\end{tabular}


Contd......

\begin{tabular}{|c|c|c|c|c|c|c|c|c|c|}
\hline District & Taluk & $\begin{array}{l}\text { Sample } \\
\text { number }\end{array}$ & Village & Variety & Season & Soil type & $\begin{array}{c}\text { No.of } \\
\text { galls/ro } \\
\text { ot } \\
\text { system }\end{array}$ & $\begin{array}{c}\text { Gall } \\
\text { Index }\end{array}$ & $\begin{array}{c}\text { Nematode } \\
\text { population in } \\
\text { soil } \\
(200 \text { cc })\end{array}$ \\
\hline \multirow{4}{*}{ Vijayapura } & \multirow{4}{*}{ Sindagi } & 17 & Bommanahalli-1 & Local & Kharif & Black soil & 15 & 3 & 38 \\
\hline & & 18 & Bommanahalli-2 & Local & Kharif & Black soil & 00 & 0 & 00 \\
\hline & & 19 & Bommanahalli-3 & Local & Kharif & Black soil & 34 & 4 & 52 \\
\hline & & 20 & Bommanahalli-4 & Local & Kharif & Black soil & 10 & 2 & 42 \\
\hline \multicolumn{7}{|c|}{ Total } & 59 & 9 & 132 \\
\hline \multicolumn{7}{|c|}{ Average } & 14.75 & 2.25 & 33.00 \\
\hline \multirow{5}{*}{ Dharwad } & \multirow{5}{*}{ Dharwad } & 21 & Dharwad-1 & Local & Kharif & Red sandy loam & 15 & 3 & 59 \\
\hline & & 22 & Dharwad-2 & Local & Kharif & Red sandyloam & 28 & 3 & 45 \\
\hline & & 23 & Narendra -1 & Local & Kharif & Red sandyloam & 19 & 3 & 62 \\
\hline & & 24 & Narendra -2 & Local & Kharif & Red sandyloam & 19 & 3 & 68 \\
\hline & & 25 & Narendra -3 & Local & Kharif & Red sandyloam & 22 & 3 & 89 \\
\hline \multicolumn{7}{|c|}{ Total } & 103 & 15 & 323 \\
\hline \multicolumn{7}{|c|}{ Average } & 20.60 & 3 & 64.60 \\
\hline
\end{tabular}


Contd...

\begin{tabular}{|c|c|c|c|c|c|c|c|c|c|c|}
\hline \multirow{6}{*}{ Bidar } & \multirow{6}{*}{\multicolumn{2}{|c|}{ Basavakalyan }} & 26 & Tadola -1 & Local & Kharif & Red sandyloam & 30 & 3 & 39 \\
\hline & & & 27 & Tadola -2 & Local & Kharif & Red sandyloam & 20 & 3 & 60 \\
\hline & & & 28 & Tadola -3 & Local & Kharif & Red sandyloam & 29 & 3 & 33 \\
\hline & & & 29 & Rajola-1 & Local & Kharif & Red sandyloam & 09 & 2 & 45 \\
\hline & & & 30 & Rajola-2 & Local & Kharif & Red sandyloam & 22 & 3 & 61 \\
\hline & & & 31 & Rajola-3 & Local & Kharif & Red sandyloam & 07 & 2 & 38 \\
\hline \multicolumn{8}{|c|}{ Total } & 122 & 16 & 276 \\
\hline \multicolumn{8}{|c|}{ Average } & 20.33 & 2.66 & 46.00 \\
\hline \multirow{3}{*}{\multicolumn{2}{|c|}{ Chikkamagaluru }} & \multirow{3}{*}{ Mudigere } & 32 & Mudigere -1 & Local & Kharif & Red sandyloam & 09 & 2 & 42 \\
\hline & & & 33 & Mudigere -2 & Local & Kharif & Red sandyloam & 28 & 3 & 54 \\
\hline & & & 34 & Mudigere -3 & Local & Kharif & Red sandyloam & 21 & 3 & 31 \\
\hline & & & \multicolumn{5}{|c|}{ Total } & 58 & 8 & 137 \\
\hline \multicolumn{8}{|c|}{ Average } & 19.30 & 2.60 & 42.33 \\
\hline \multicolumn{8}{|c|}{ Grand total } & 695.00 & 96.00 & 1984 \\
\hline \multicolumn{8}{|c|}{ Average } & 19.83 & 2.74 & 54.23 \\
\hline
\end{tabular}




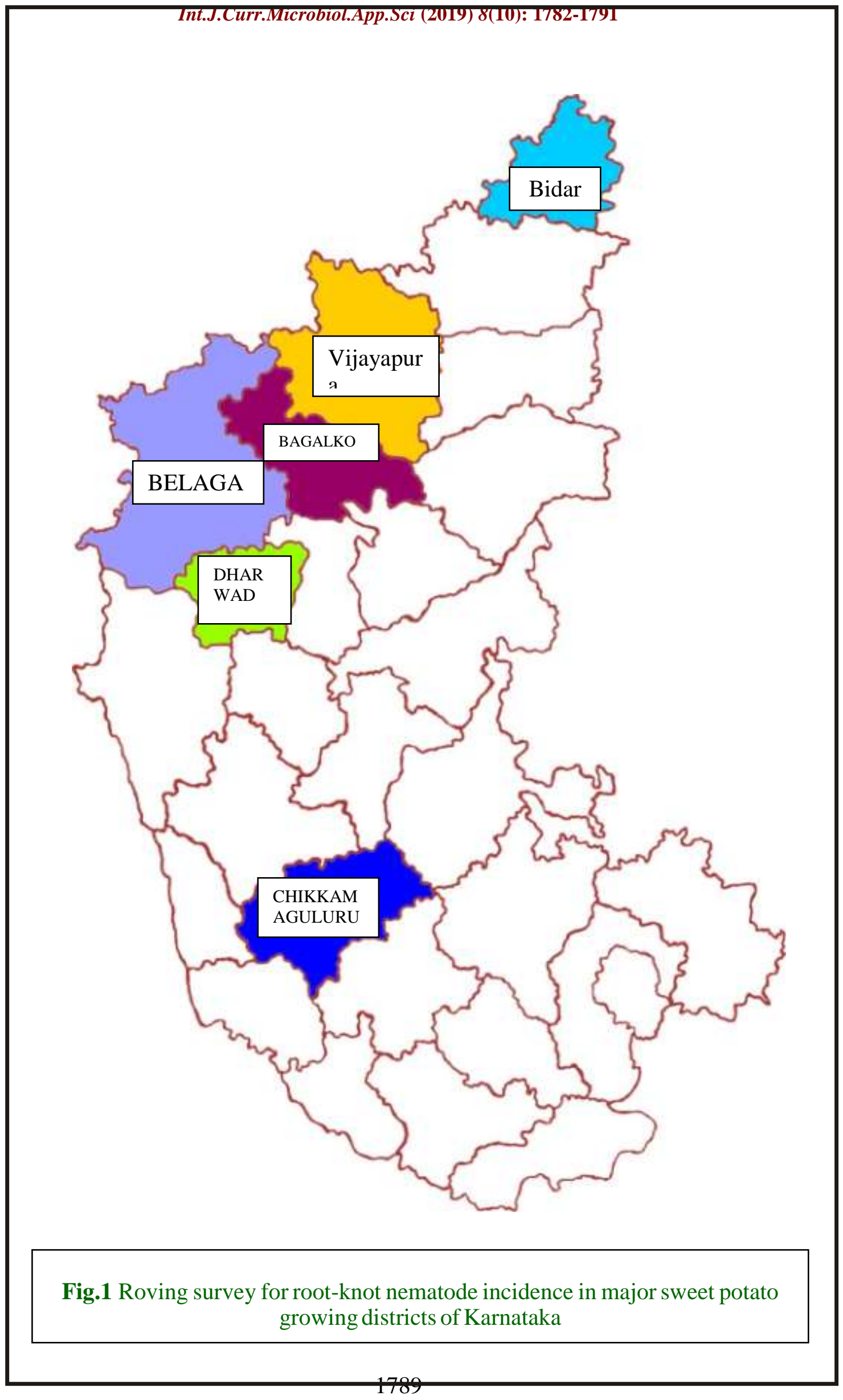


Maximum soil nematode population was recorded in Narendra (3) field (89) followed by Narendra (2) field (68) and Narendra (1) field (62). The minimum population was recorded in Dharwad (2) field (45) followed by Dharwad (2) field (59).

In Dharwad district, on an average, the number of galls per root system was 20.6 with the gall index of 3.0 and soil nematode population of 64.60 was recorded (Table 2).

The results of the survey in Bidar district revealed that, the number of galls per root system was ranged from 7-30 with highest in Tadola (1) field (30) followed by Tadola (3) field (29) and Rajola (2) field (22). The least number of galls per root system (07) was recorded in Rajola (3) field followed by Rajola (1) field (9). The maximum gall index of (3) was recorded in Tadola (1, 2 \& 3) and Rajola (2) fields and minimum (2) in Rajola (1) and Rajola (3) fields.

The highest soil nematode population was observed in Rajola (2) field (61) followed by Tadola (2) field (60) and Rajola (1) field (45). The minimum population of 33 was recorded from Tadola (3) field followed by Tadola (1) field (39). In Bidar district, on an average, the number of galls per root system was 20.33, gall index of 2.66 and soil nematode population of 46.00 was recorded.

In Chikkamagaluru district, the number of galls per root system was ranged from 9-28. Maximum number of galls (28) was recorded in Mudigere (2) field followed by Mudigere (3) field (21) and minimum numbers of galls were recorded in Mudigere (1) field (9). The maximum gall index (3) was found in Mudigere ( $2 \& 3)$ and minimum gall index (2) in Mudigere (1) field.

The nematode population per $200 \mathrm{cc}$ soil was ranged from 31-54. The maximum soil nematode population (54) was recorded in
Mudigere (2) field followed by Mudigere (1) field (42) as against minimum population (31) in Mudigere (3) field.

On an average, among all the six districts surveyed, the maximum number of galls per root system (22.50) was found in Bagalkot district followed by Belagavi (21.50), Dharwad (20.60), Bidar (20.33), Chikkamagaluru (19.83) and Vijayapura (14.75).

The average highest gall index of (3.10) was recorded in Belagavi district followed by Dharwad (3.0), Bagalkot (2.87), Bidar (2.66) and Chikkamaguluru (2.60) and Vijayapura (2.25).

The average highest soil nematode population (74.25) was seen in Belagavi district followed by Bagalkot (65.25), Dharwad (64.6), Bidar (46.00), Chikkamagaluru (42.33) and Vijayapura (33.00).

Present findings with respect to infestation of root-knot nematode in sweet potato growing fields are in conformity with the results of by Karuri et al., (2016), Olabiyi et al., (2002) and Iwahori et al., (2002) who reported that Meloidogyne spp. was the most common in the area surveyed. Several other plant parasitic nematodes associated with sweet potato have also been reported viz., Rotylenchulus reniformis, Helicotylenchus dihystera, Hoplolaimus indicus, Tylenchorhynchus spp. and Xiphinema spp. (Ramakrishnan and Mohandas, 1996).

\section{Acknowledgement}

The authors are thankful to icar-aicrp on fruits, arabhavi centre for providing the required research facilities and support

\section{References}

Ayoub, R. M., 1977, Plant Pathology An Agricultural training Aid. State 
California, Dept. Food and Agric. Sacromento, USA, p.156.

Anonymous, 2017, Indian horticulture database, www.nhb.gov.in.

Collins, W. W., Carey, E. E., Mok, I. G., Thompson, P. and Da Peng, Z., 1999, Utilization of sweet potato genetic resources to develop insect resistance. In: S.L. Clement and S.S. Quisenberry (eds.), Global Plant Genetic Resources for Insect-Resistant Crops. CRC Press, Boca Raton, FL. 193-205.

Iwahori, H., Sano, Z. and Ogawa, T., 2002, Distribution of main plant-parasitic nematodes in sweet potato and taro fields in Kyushu and Okinawa, Japan. In Proceedings of the Association for Plant Protection of Kyushu, 46: 112117.

Karuri, H. W., Olago, D., Neilson, R., Mararo, E. and Villinger, J., 2017, A survey of root knot nematodes and resistance to Meloidogyne incognita in sweet potato varieties from Kenya fields. Crop Prot., 92: 114-121.

Olabiyi, T. I., Oluwatoyin, A., Fabiyi, Atungwu, J. J. and Adepoju, I. O., 2002, Plant parasitic nematode associated with sweet potato in Nigeria. Acad, J. Agric. Res., 1(4): 3234.

Oliveira, A. P., Silva, J. E. L., Pereira, W. E. and Barbosa, L. J. N., 2005, Productivity of yams, in function of organic and mineral fertilization and times of harvest. J. Nematol., 19(2): 144-147.

Ramakrishnan, S. and Mohandas, C., 1996, Density and frequency of various plant parasitic nematodes in sweet potato growing areas of Kerala. J. Root crops., 22(2): $112-114$.

\section{How to cite this article:}

Amaresh, H., V. Kantharaju, S. Amruta Bhat, K. Ramachandra Naik and Mahesh, Y. S. 2019. Roving Survey for Root-Knot Nematode in Major Sweet Potato Growing Districts of Karnataka, India. Int.J.Curr.Microbiol.App.Sci. 8(10): 1782-1791. doi: https://doi.org/10.20546/ijcmas.2019.810.207 